JRPB, Vol. 6, No. 2, September 2018, Hal. 131-140

DOI: https://doi.org/10.29303/jrpb.v6i2.87

ISSN 2301-8119, e-ISSN 2443-1354

Tersedia online di http://jrpb.unram.ac.id/

\title{
EVALUASI KESESUAIAN LAHAN UNTUK KOMODITAS PADI DENGAN MEMANFAATKAN APLIKASI SISTEM INFORMASI GEOGRAFIS (SIG) DI KABUPATEN LOMBOK TENGAH
}

\author{
Land Suitability Evaluation for Rice Commodity by Using Geographic Information \\ System (GIS) In Central Lombok Regency
}

\author{
Fitriani Risti Fauzi ${ }^{1}$, Sirajuddin H. Abdullah ${ }^{2, *)}$, Asih Priyati \\ ${ }^{1}$ Alumni Program Studi Teknik Pertanian, FATEPA Unram \\ ${ }^{2}$ Staf Pengajar Program Studi Teknik Pertanian, FATEPA Unram
}

Email $^{*}$ : sirajuddinhajiabdullah@gmail.com

\begin{abstract}
Land suitability evaluation for agricultural commodity can be arranged based on land condition. Since every plants type have a spesific growth requirement that suitable with the region characteristic, to grow and rise optimally. The aim of this research was to determine level of suitability land for "Sawah" rice and "Gogo" rice in Lombok tengah region base on some aspect, i.e. topography, soil type, and climate. This research also conducted to determine land characteristic in Central Lombok Regency. The method used in this research was by matching the region land condition data with the existence land suitability class criteria for "Sawah" rice and "Gogo" rice. Land suitability evaluation maps was arranged by using ArcView GIS 10.5. Observed parameters were land characteristic and level of land suitability for "Sawah" rice and "Gogo" rice in Central Lombok Regency. Generally, Central Lombok Regency with area 1.208,39 km² has elevation about 0-3000 meters above sea water level and slope level range from 0 (zero) to more than 150\%. Based on type of soil, i.e. drainage, Central Lombok Regency was dominated by impeded drainage, good drainage and medium drainage. Land texture was dominated by sandy loam, loam, clay loam and clay with land's effective depth range from $80-120 \mathrm{~cm}$, while the $\mathrm{pH}$ of the land range from 5-8. The precifitation of this area range from 1.000-3.000 mm/year. The level of land suitability for "Sawah" rice in Central Lombok Regency and its area are very suitable (S1) covers $298.203 \mathrm{Ha}$, moderately suitable (S2) covers $1013.165 \mathrm{Ha}$, marginally suitable (S3) covers $64828.164 \mathrm{Ha}$, currently suitable (N1) covers $20832.869 \mathrm{Ha}$, permanently not suitable (N2) covers 20524.485 Ha. The level of land suitability for "Gogo" rice in Central Lombok Region and its area are very suitable (S1) covered 0, moderately suitable (S2) covered $34485.186 \mathrm{Ha}$, marginally suitable (S3) covered $64828.164 \mathrm{Ha}$, currently suitable (N1) covered $4591.509 \mathrm{Ha}$, permanently not suitable (N2) covered 13260.590 Ha.
\end{abstract}

Keywords: land evaluation, Central Lombok Regency, rice, GIS 


\begin{abstract}
ABSTRAK
Evaluasi kesesuaian lahan untuk suatu komoditas pertanian dapat disusun berdasarkan kondisi lahan. Hal tersebut dikarenakan setiap jenis tanaman mempunyai syarat tumbuh tertentu untuk dapat tumbuh dan berkembang secara optimal sesuai dengan karakteristik lahan suatu wilayah. Penelitian ini bertujuan untuk mengetahui kelas kesesuaian lahan untuk tanaman padi Sawah dan padi Gogo di Kabupaten Lombok Tengah berdasarkan beberapa aspek yaitu topografi, jenis tanah dan iklim. Tujuan lain dari penelitian ini adalah untuk mengelahui karakteristik sumber daya lahan di kabupaten Lombok tengah. Metode yang digunakan dalam penelitian ini adalah dengan proses pencocokan (matching) data kondisi wilayah kajian dengan kriteria kelas kesesuaian lahan untuk tanaman padi Sawah dan padi Gogo yang telah ada. Pembuatan peta kesesuaian lahan disusun menggunakan ArcView GIS 10.5. Adapun parameter yang diamati adalah karakteristik wilayah (iklim, tanah dan topografi) serta tingkat kesesuaian lahan untuk tanaman padi Sawah dan padi Gogo di Kabupaten Lombok Tengah. Secara umum, Kabupaten Lombok Tengah dengan luas sekitar 1.208,39 $\mathrm{km}^{2}$ memiliki elevasi sekitar 0-3000 m.dpl dengan tingkat kemiringan dari 0 (nol) sampai lebih dari $150 \%$. Berdasarkan jenis tanah yaitu drainase, Kabupaten Lombok Tengah didominasi drainase Terhambat, drainase Baik, dan drainase Sedang. Sedangkan tektur tanah yang mendominasi adalah Lempung Berpasir (Sandy Loam), Lempung (Loam), Lempung Berliat (Clay Loam) dan Liat (Clay), dengan kedalaman efektif tanah antara $80 \mathrm{~cm}$ sampai dengan $120 \mathrm{~cm}, \mathrm{pH}$ tanah berkisar antara 5 sampai dengan 8. Jumlah curah hujan wilayah berkisar antara 1.000-3.000 mm/tahun. Kelas kesesuaian untuk tanaman padi Sawah beserta luasannya adalah Sangat Sesuai (S1) seluas 298.203 Ha, Cukup Sesuai (S2) seluas 1013.165 Ha, Sesuai Marginal (S3) seluas 64828.164 Ha, Tidak Sesuai Saat Ini (N1) seluas 20832.869 Ha, Tidak Sesuai Selamanya (N2) seluas 20524.485 Ha. Kelas kesesuaian untuk tanaman padi Gogo di Kabupaten Lombok Tengah beserta luasannya adalah Sangat Sesuai (S1) seluas 0, Cukup Sesuai (S2) seluas 34485.186 Ha, Sesuai Marginal (S3) seluas 64279.951 Ha, Tidak Sesuai Saat Ini (N1) seluas 4591.509 Ha, Tidak Sesuai Selamanya (N2) seluas 13260.590 Ha.
\end{abstract}

Kata kunci: evaluasi lahan, Kabupaten Lombok Tengah, padi, SIG 


\section{PENDAHULUAN}

\section{Latar Belakang}

Sejalan dengan peningkatan jumlah penduduk dan perkembangan industri, diperkirakan permintaan produksi pertanian sebagai bahan pangan pokok dan bahan baku industri akan terus meningkat (Nazam dkk., 2014). Di Indonesia tanaman pangan yang digunakan oleh masyarakat masih terbatas pada beberapa jenis, salah satunya adalah padi. Sampai saat ini ketergantungan pangan padi masih sangat besar. Dari total kalori yang dikonsumsi oleh masyarakat, hampir $60 \%$ dicukupi oleh beras (Purwono dan Purnamawati, 2010). Bila dilihat rata-rata pengeluaran per kapita sebulan menurut kelompok makanan, yaitu pengeluaran untuk makanan dan minuman menempati urutan tertinggi yang diikuti oleh pengeluaran padi-padian (Anonim ${ }^{1}$, 2015).

Selama ini, produksi padi nasional masih mengandalkan sawah irigasi. Namun, ke depannya bila hanya mengandalkan padi Sawah irigasi akan menghadapi banyak kendala. Hal tersebut disebabkan banyaknya lahan sawah irigasi subur yang beralih fungsi ke penggunaan lahan non pertanian, tingginya biaya pencetakan lahan sawah baru, dan berkurangnya debit air. Di lain pihak lahan kering tersedia cukup luas dan pemanfaatannya untuk pertanaman padi Gogo belum optimal, sehingga ke depan produksi padi Gogo juga dapat dijadikan andalan produksi padi nasional (Anonim ${ }^{2}$, 2009).

Salah satu tantangan dalam pembangunan pertanian adalah adanya kecenderungan menurunnya produktivitas lahan. Di sisi lain, sumberdaya alam terus menurun sehinga perlu diupayakan untuk tetap menjaga kelestariannya. Demikian pula dalam usaha tani padi, agar usaha tani padi dapat berkelanjutan, maka teknologi yang diterapkan harus memperhatikan faktor lingkungan, baik lingkungan fisik maupun lingkungan sosial, sehingga agribisnis padi dapat terlanjutkan (Anonim² ${ }^{2}$ 2009).

Suatu analisis perencanaan pertanian tidak akan terlepas dari faktorfaktor yang mempengaruhinya, yang paling utama adalah lingkungan fisik (tanah dan iklim), faktor tanah dipertimbangkan sebagai faktor yang dapat dimodifikasi dan iklim merupakan faktor yang tidak dapat dimodifikasi. Oleh karena itu, dalam suatu perencanaan pertanian analisis lingkungan merupakan hal penting yang mendukung keberhasilan perencanaan tersebut.

Studi evaluasi lahan untuk menentukan tingkat kesesuaiaan lahan dalam rangka pengembangan potensi budidaya tanaman padi Sawah dan padi Gogo di Kabupaten Lombok Tengah sangat dibutuhkan. Oleh Karen itu penting untuk dilakukan penelitian yang bejudul Evaluasi Tingkat Kesesuaian Lahan untuk Komoditas Padi dengan Memanfaatkan Aplikasi Sistem Informasi Geografis (SIG) di Kabupaten Lombok Tengah. Hal ini dimaksudkan untuk mengetahui potensi-potensi wilayah di Kabupaten Lombok Tengah yang memiliki kelayakan untuk pengembangan budidaya padi Sawah dan padi Gogo sesuai dengan kondisi setempat. 


\section{Tujuan Penelitian}

Tujuan utama dilaksanakannya penelitian ini adalah untuk mengetahui bagaimana kelas kesesuaian lahan untuk tanaman padi Sawah dan padi Gogo di Kabupaten Lombok Tengah berdasarkan aspek lingkungan fisik yaitu kelerengan, jenis tanah, curah hujan dan suhu. Tujuan lain dari penelitian ini adalah untuk mengetahui bagaimana karakteristik sumber daya lahan (topografi, iklim, dan tanah) di Kabupaten Lombok Tengah.

\section{Batasan Masalah}

Untuk menyederhanakan proses peneilitian yang akan dilakukan maka diperlukan batasan-batasan masalah sebagai berikut:

1. Mengetahui karakteristik iklim, tanah dan topografi di Kabupaten Lombok Tengah

2. Mengetahui kondisi yang sesuai untuk syarat tumbuh tanaman padi Sawah dan padi Gogo

3. Mengetahui wilayah mana saja yang berpotensi untuk pengembangan padi Sawah dan padi Gogo di Kabupaten Lombok Tengah

4. Mengetahui tingkat kesesuaian lahan untuk tanaman padi Sawah dan padi Gogo di Kabupaten Lombok Tengah.

\section{METODE PENELITIAN}

\section{Waktu dan Tempat Penelitian}

Penelitian dilaksanakan di

Kabupaten Lombok Tengah Provinsi Nusa Tenggara Barat pada bulan September 2016.

\section{Alat dan Bahan Penelitian}

Pada penelitian ini digunakan berbagai peralatan dan data guna mendukung kegiatan penelitian, peralatan dan data tersebut adalah:

1. Data sekunder terdiri dari data jenis tanah, ketinggian, kelerengan, curah hujan dan suhu udara.

2. Data spasial berupa peta administrasi, peta jenis tanah, peta kelerengan, peta ketinggian, peta curah hujan peta suhu udara dan peta tata guna lahan.

3. Seperangkat PC (Personal Computer) dengan perangkat lunak (Software) pengolah kata (Microsoft Word), Microsoft Excel, dan ArcView GIS.

\section{Metode}

Metode yang digunakan dalam Penelitian ini adalah metode deskriptif, yaitu metode penelitian yang berusaha untuk menggambarkan kondisi suatu objek dan dituangkan dalam bentuk peta, gambar, tabel atau grafik. Penelitian ini dilaksanakan melalui beberapa tahapan metode yaitu:

1. Pengumpulan Data

Pada tahapan ini dikumpulkan berbagai macam data dan informasi yang dibutuhkan pada penelitian ini yang terdiri dari data sekunder berupa data iklim dan tanah, baik itu data spasial, maupun data sekunder lainnya (curah hujan, jenis tanah, topografi dan lainlain).

2. Analisis Kondisi Fisik Kabupaten Lombok Tengah

Analisis kondisi fisik Kabupaten Lombok Tengah meliputi analisis kondisi tanah (jenis tanah, ketinggian, kelerengan) dan karakteristik iklim (klasifikasi iklim, curah hujan dan suhu udara).

3. Klasifikasi Kelas Kesesuaian Lahan 
Evaluasi kesesuaian lahan yang digunakan mengacu kepada sistem klasifikasi lahan yang dikembangkan oleh Food and Agriculture Organization (FAO) (1976). Kerangka dari sistem klasifikasi lahan ini mengenal 4 katagori, yaitu: ordo, kelas, sub-kelas, dan unit

4. Penentuan Tingkat Kesesuaian Iklim, Tanah, Topografi

Penentuan tingkat kesesuaian lahan terdiri dari 7 variabel pembatas yaitu: kelerengan, drainase, tekstur, kedalaman solum, $\mathrm{pH}$ tanah, curah hujan dan suhu udara.

Tingkat kesesuaian iklim didasarkan dari data sekunder rata-rata curah hujan bulanan selama 10 tahun pengamatan (2006-2015) di Kabupaten Lombok Tengah.
Suhu udara dapat diduga dari data ketinggian wilayah Kabupaten Lombok Tengah melalui persamaan Braak (1928) dalam Ritung, dkk., (2007):

$\mathrm{Tz}=26,3{ }^{\circ} \mathrm{C}-(0,01 \times$ Elevasi dalam meter $\left.\mathrm{x} 0,6{ }^{0} \mathrm{C}\right)$.

5. Kriteria Kelas Kesesuaian Lahan

Kriteria kelas kesesuaian lahan untuk tanaman padi Sawah dan padi Gogo mengacu pada LPRE II 1994 dan PPT 2003 yang dimodifikasi oleh Hardjowigeno dan Widiatmaka (2007). Kriteria kesesuaian lahan untuk tanaman padi Sawah dan padi Gogo ditunjukkan pada Tabel 1 dan Tabel 2.

Tabel 1. Kriteria Kesesuaian Lahan untuk Tanaman Padi Sawah

\begin{tabular}{|c|c|c|c|c|c|c|}
\hline \multirow{2}{*}{ No } & \multirow{2}{*}{ Karakteristik lahan } & \multicolumn{5}{|c|}{ Kesesuaian lahan } \\
\hline & & S1 & S2 & S3 & $\mathrm{N} 1$ & $\mathrm{~N} 2$ \\
\hline 1 & Temperatur $\left({ }^{\circ} \mathrm{C}\right)$ & $>24-29$ & $22-24$ & $18-22$ & $\mathrm{Td}$ & $<18$ \\
\hline 2 & $\begin{array}{l}\text { Curah } \\
(\mathrm{mm} / \mathrm{thn})\end{array}$ & $>1500$ & $1200-1500$ & $\begin{array}{l}800- \\
1200\end{array}$ & $\mathrm{Td}$ & $<800$ \\
\hline 3 & Drainase & $\underset{\mathrm{t}}{\text { terhamba }}$ & $\begin{array}{c}\text { Agak } \\
\text { terhambat }\end{array}$ & $\begin{array}{c}\text { Sedang, } \\
\text { baik }\end{array}$ & $\begin{array}{l}\text { Agak } \\
\text { cepat, } \\
\text { cepat }\end{array}$ & $\begin{array}{c}\text { Sangat } \\
\text { cepat }\end{array}$ \\
\hline 4 & Tekstur tanah & $\begin{array}{l}\text { SCL, } \\
\text { SiL, Si, } \\
\text { CL }\end{array}$ & $\begin{array}{c}\text { SL, L, } \\
\text { SiCL, C, } \\
\text { SiC }\end{array}$ & $\begin{array}{c}\text { LS, Str } \\
\text { C }\end{array}$ & $\mathrm{Td}$ & $\begin{array}{c}\text { Kerikil, } \\
\text { pasir }\end{array}$ \\
\hline 5 & Solum (cm) & $>50$ & $40-50$ & $25-40$ & $20-25$ & $<20$ \\
\hline 6 & $\mathrm{pH}$ tanah & $5,5-7$ & $\begin{aligned} & >7-8 \\
> & 4,5-5,5\end{aligned}$ & $\begin{array}{l}>8-8,5 \\
4-<4,5\end{array}$ & - & $\begin{array}{c}>8,5 \\
<4\end{array}$ \\
\hline 7 & Lereng & $<3$ & $3-8$ & $>8-15$ & $>15-25$ & $>25$ \\
\hline
\end{tabular}

Sumber: Hardjowigeno dan Widiatmaka (2007). 
Tabel 2. Kriteria Kesesuaian Lahan untuk Tanaman Padi Gogo

\begin{tabular}{|c|c|c|c|c|c|c|}
\hline \multirow{2}{*}{ No } & \multirow{2}{*}{ Karakteristik lahan } & \multicolumn{5}{|c|}{ Kesesuaian Lahan } \\
\hline & & S1 & $\mathrm{S} 2$ & S3 & $\mathrm{N} 1$ & $\mathrm{~N} 2$ \\
\hline \multirow[t]{2}{*}{1} & Temperatur $\left({ }^{\circ} \mathrm{C}\right)$ & $20-27$ & $>27-30$ & $>30-35$ & $\mathrm{Td}$ & $>13$ \\
\hline & & & $18-20$ & $18-<18$ & - & $<16$ \\
\hline 2 & $\begin{array}{l}\text { Curah hujan } \\
\text { (mm/thn) }\end{array}$ & $>1500$ & $1000-1500$ & $750-<1000$ & $\mathrm{Td}$ & $<750$ \\
\hline 3 & Drainase & $\begin{array}{l}\text { Baik, } \\
\text { sedang }\end{array}$ & $\begin{array}{c}\text { Terhambat, } \\
\text { Agak } \\
\text { terhambat }\end{array}$ & $\begin{array}{c}\text { Sangat } \\
\text { terhambat, } \\
\text { agak cepat }\end{array}$ & $\mathrm{Td}$ & cepat \\
\hline 4 & Tekstur tanah & $\begin{array}{c}\text { SCL, } \\
\text { SiL, Si, } \\
\text { CL, } \\
\text { SiCL }\end{array}$ & $\underset{\mathrm{C}}{\mathrm{SL}, \mathrm{L}, \mathrm{SC}}$ & $\begin{array}{l}\mathrm{LS}, \mathrm{SiC} \\
\text { Str C }\end{array}$ & $\mathrm{Td}$ & $\begin{array}{c}\text { Kerikil, } \\
\text { pasir }\end{array}$ \\
\hline 5 & Solum $(\mathrm{cm})$ & $>60$ & $>40-60$ & $20-40$ & $\mathrm{Td}$ & $<20$ \\
\hline \multirow[t]{2}{*}{6} & $\mathrm{pH}$ tanah & $5-6$ & $>6-7$ & $>7-8,5$ & $\mathrm{Td}$ & $>8,5$ \\
\hline & & & $>4,5-5$ & $4-4,5$ & & $<4.5$ \\
\hline 7 & Lereng & $0-8$ & $8-15$ & $15-50$ & - & $>50$ \\
\hline
\end{tabular}

Sumber: Hardjowigeno dan Widiatmaka (2007).

Keterangan:

$\begin{array}{llll}\mathrm{Td} & : \text { Tidak berlaku } & \mathrm{Si} & : \text { Debu } \\ \mathrm{S} & : \text { Pasir } & \mathrm{Str} \mathrm{C} & : \text { Liat Berstruktur } \\ \mathrm{L} & \text { : Lempung } & & \end{array}$

6. Pembuatan Peta Kesesuaian Lahan

Pembuatan peta kesesuaian lahan untuk tanaman padi dilakukan dengan menggunakan metode aplikasi Sistem Informasi Geografis (SIG). Pembuatan peta kesesuaian lahan dilakukan dengan penggabungkan atau tumpang tindih (overlay) antara beberapa variabel pembatas yang telah dijelaskan sebelumnya. Dari hasil penggabungan dapat ditentukan faktor pembatas yang memberikan pengaruh terbesar bagi pertumbuhan tanaman padi Sawah dan padi Gogo.

\section{HASIL DAN PEMBAHASAN}

Secara umum, Kabupaten Lombok Tengah dengan luas sekitar $1.208,39 \mathrm{~km}^{2}$ memiliki elevasi sekitar 0-3000 m.dpl dengan tingkat kemiringan dari 0 (nol) sampai lebih dari 150\%. Berdasarkan jenis tanah yaitu drainase, Kabupaten Lombok Tengah didominasi drainase Terhambat, drainase Baik, dan drainase Sedang. Sedangkan tektur tanah yang mendominasi adalah Lempung Berpasir (Sandy Loam), Lempung (Loam), Lempung Berliat (Clay Loam) dan Liat (Clay), dengan kedalaman efektif tanah antara $80 \mathrm{~cm}$ sampai dengan $120 \mathrm{~cm}, \mathrm{pH}$ tanah berkisar antara 5 sampai dengan 8 . Jumlah curah hujan wilayah berkisar antara 1.000-3.000 mm/tahun.

\section{Arahan Pewilayahan Komoditas Pertanian}

Proses evaluasi lahan untuk menentukan kelas kesesuaian lahan yang didasark an atas karakteristik lahan (kondisi tanah, iklim dan topografi) dilakukan dengan metode penggabungan atau tumpang tindih (overlay). Dari hasil 
tumpang tindih dengan menggunakan hukum minimum dapat ditentukan faktor pembatas yang memberikan pengaruh terbesar bagi pertumbuhan tanaman padi Sawah dan padi Gogo. Gambar 1 dan Gambar 2 memperlihatkan Peta Kelas Kesesuaian Lahan Padi Sawah dan padi Gogo di Kabupaten Lombok Tengah.
Hasil dari evaluasi lahan yang telah dilakukan, didapatkan beberapa kelas kesesuaian untuk tanaman padi Sawah dan padi Gogo di Kabupaten Lombok Tengah seperti yang disajikan pada Tabel 3 dan 4 berturut-turut.

Tabel 3. Kelas Kesesuaian Padi Sawah

\begin{tabular}{lccccc}
\hline \multirow{2}{*}{ Kecamatan } & \multicolumn{5}{c}{ Luas (ha) } \\
\cline { 2 - 6 } & $\mathrm{S} 1$ & $\mathrm{~S} 2$ & $\mathrm{~S} 3$ & $\mathrm{~N} 1$ & $\mathrm{~N} 2$ \\
\hline Batukliang & 0 & 661,585 & 3492,544 & 934,984 & 10,978 \\
Batukliang Utara & 0 & 444,341 & 7125,262 & 3192,832 & 5142,241 \\
Janapria & 0 & 0 & 5629,592 & 1377,029 & 36.965 \\
Jonggat & 3,360 & 3166,108 & 3134,008 & 511,831 & 25,399 \\
Kopang & 0 & 794,469 & 3594,023 & 925,773 & 543,815 \\
Praya & 0 & 431,460 & 3635,866 & 704,276 & 7,265 \\
Praya Barat & 283,418 & 1007,951 & 7917,910 & 2285,829 & 4573,280 \\
Praya Barat Daya & 11,424 & 1164,434 & 2420,952 & 1907,227 & 7092,289 \\
Praya Tengah & 0 & 0 & 5746,661 & 352,845 & 13,610 \\
Praya Timur & 0 & 6,519 & 6350,943 & 1753,214 & 96,327 \\
Pringgarata & 0 & 972,154 & 2805,964 & 599,138 & 59,776 \\
Pujut & 0 & 1464,143 & 12974,44 & 6287,892 & 2922,540 \\
\hline
\end{tabular}
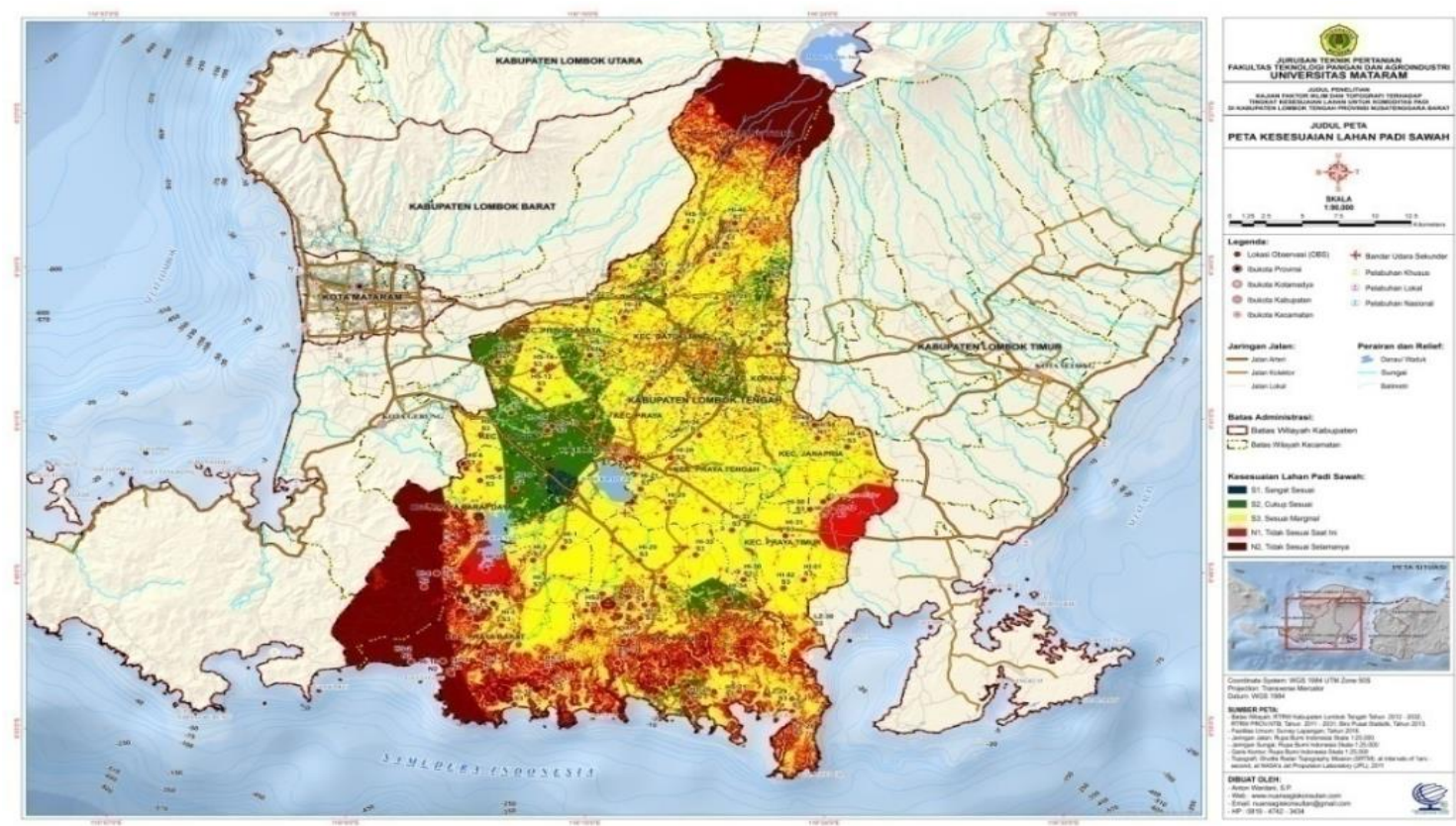

Gambar 1. Peta Kelas Kesesuaian Lahan Padi Sawah 
Kelas kesesuaian Sangat Sesuai (S1) untuk tanaman padi Sawah berada di kecamatan Jonggat sebesar 3,360 ha, kecamatan Praya Barat sebesar 283,418 ha dan kecamatan Praya Barat Daya sebesar 11,424 ha. Kelas kesesuaian Cukup Sesuai (S2) dengan daerah yang memiliki luasan paling besar berada di kecamatan Jonggat sebesar 3166,108 ha. Kelas kesesuaian Sesuai Marginal (S3) dengan daerah yang memiliki luasan paling besar berada di kecamatan Praya Barat sebesar 7917,910 ha. Kelas Kesesuaian Tidak Sesuai Saat Ini (N1) dengan daerah yang memiliki luasan paling besar berada di kecamatan Pujut sebesar 6287,892. Kelas Kesesuaian Tidak Sesuai untuk Selamanya (N2) dengan daerah yang memiliki luasan paling besar berada di kecamatan Praya Barat Daya sebesar 7092,289 ha.

Tabel 4. Kelas Kesesuaian Padi Gogo

\begin{tabular}{lccccc}
\hline \multirow{2}{*}{ Kecamatan } & \multicolumn{5}{c}{ Luas (Ha) } \\
\cline { 2 - 6 } & $\mathrm{S} 1$ & $\mathrm{~S} 2$ & $\mathrm{~S} 3$ & $\mathrm{~N} 1$ & $\mathrm{~N} 2$ \\
\hline Batukliang & 0 & 0 & 3440,840 & 324,672 & 1334,580 \\
Batukliang Utara & 0 & 1012,148 & 11674,810 & 116,306 & 3101,414 \\
Janapria & 0 & 4934,332 & 1708,505 & 374,191 & 26,837 \\
Jonggat & 0 & 5639,211 & 744,934 & 441,111 & 15,450 \\
Kopang & 0 & 1621,577 & 3454,350 & 393,738 & 388,841 \\
Praya & 0 & 2524,509 & 1610,832 & 638,823 & 4,704 \\
Praya Barat & 0 & 3167,244 & 9715,609 & 319,051 & 2866,487 \\
Praya Barat Daya & 0 & 2443,495 & 3764,488 & 158,985 & 6229,360 \\
Praya Tengah & 0 & 1041,675 & 4749,808 & 308,023 & 13,610 \\
Praya Timur & 0 & 5587,451 & 2090,584 & 486,602 & 42,367 \\
Pringgarata & 0 & 1692,495 & 2466,839 & 260,175 & 17,044 \\
Pujut & 0 & 3486,307 & 18839,240 & 769,832 & 553,637 \\
\hline
\end{tabular}
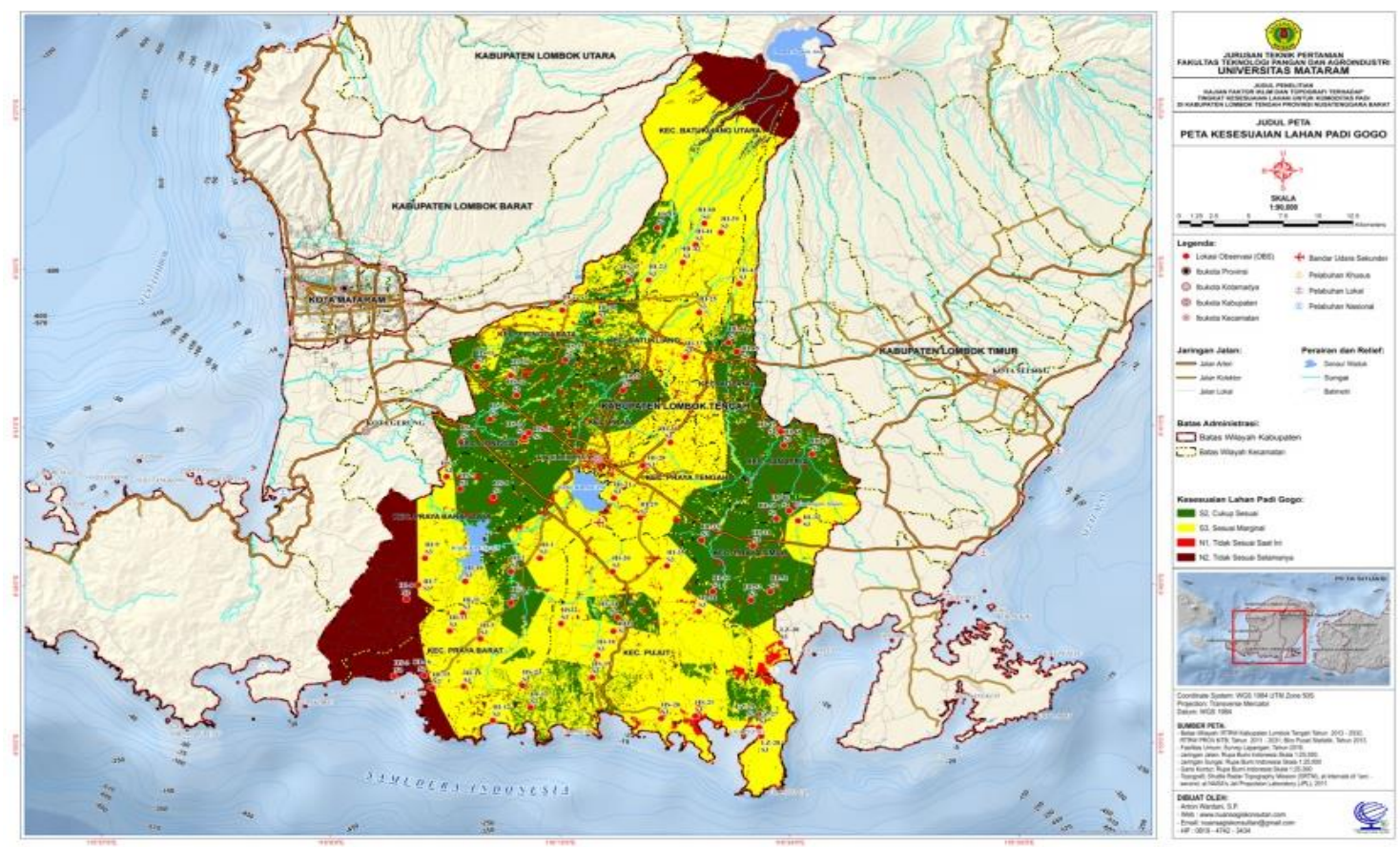

Gambar 2. Peta Kelas Kesesuaian Lahan Padi Gogo 
Sama halnya dengan padi Sawah, berdasarkan Tabel 2 terlihat bahwa kelas kesesuaian lahan untuk tanaman padi Gogo juga tidak banyak daerah yang mempunyai kesesuaian yang sangat tinggi. Bahkan tidak ada daerah yang memiliki kelas kesesuaian Sangat Sesuai (S1). Sebagian besar wilayah Kabupaten Lombok Tengah termasuk kelas Cukup Sesuai (S2). Namun sebagian besar juga masih bisa dikatakan sesuai untuk pengembangan padi Gogo.

Kelas kesesuaian Sangat Sesuai (S1) untuk tanaman padi Gogo adalah 0. Kelas kesesuaian Cukup Sesuai (S2) dengan daerah yang memiliki luasan paling besar berada di kecamatan Jonggat sebesar 5639,211 ha. Kelas Kesesuaian Sesuai Marginal (S3) dengan daerah yang memiliki luasan paling besar berada di Kecamatan Pujut sebesar 18839,240 ha. Kelas Kesesuaian Tidak Sesuai Saat Ini (N1) dengan daerah yang memiliki luasan paling besar berada di Kecamatan Pujut sebesar 769,832 ha. Kelas Kesesuaian Tidak Sesuai untuk Selamanya (N2) dengan daerah yang memiliki luasan paling besar berada di Kecamatan Praya Barat Daya sebesar 6229,360 ha.

Biasanya, dalam proses evaluasi kesesuaian lahan, tingkat kesesuaian yang dihasilkan tidak banyak daerah yang mempunyai kesesuaian yang sangat tinggi atau kelas kesesuaian Sangat Sesuai (S1). Hal ini disebabkan karena kelas kesesuaian lahan yang ditampilkan adalah kelas kesesuaian lahan terjelek (terendah).

Faktor pembatas yang memberikan pengaruh terbesar bagi pertumbuhan tanaman atau disebut dengan kesesuaian lahan aktual. Untuk meningkatkan kelas kesesuaian yang dihasilkan atau disebut dengan kesesuaian lahan potensial, perlu dilakukan perbaikan. Kelas kesesuaian lahan yang dihasilkan juga belum mempertimbangkan kondisi irigasi di daerah penelitian, sehingga masih dibutuhkan penelitian lebih lanjut untuk dapat dimanfaatkan secara optimal.

Lahan secara alami mempunyai kualitas lahan yang rendah dapat diperbaiki menjadi kualitas lahan yang lebih tinggi dengan menggunakan teknologi. Namun demikian, tidak semua kualitas atau karakteristik lahan dapat diperbaiki dengan teknologi yang ada pada saat ini, atau diperlukan tingkat pengolahan yang tinggi untuk dapat memperbaikinya.

\section{KESIMPULAN DAN SARAN}

\section{Kesimpulan}

Berdasarkan hasil analisis kesesuaian lahan yang telah dilakukan, dapat disimpulkan bahwa:

1. Karakteristik iklim, tanah dan topografi di Kabupaten Lombok Tengah berbeda-beda untuk masingmasing daerah, sehingga tingkat kesesuaian untuk tanaman padi Sawah dan padi Gogo yang dihasikan juga berbeda-beda.

2. Tidak banyak daerah yang mempunyai kesesuaian yang sangat tinggi untuk tanaman padi Sawah dan padi Gogo di Kabupaten Lombok Tengah. Sebagian besar wilayah Kabupaten Lombok Tengah termasuk kelas Cukup Sesuai (S2) dan Sesuai Marginal (S3). Kelas kesesuaian tertinggi untuk tanaman padi Sawah katagori Sangat Sesuai 
(S1) berada di kecamatan Praya Barat sebesar 283,418 ha, Cukup Sesuai (S2) berada di kecamatan Jonggat sebesar 3166,108 ha, Sesuai Marginal (S3) berada di kecamatan Praya Barat sebesar 7917,910 ha, Tidak Sesuai Saat Ini (N1) berada di kecamatan Pujut sebesar 6287,892 ha, Tidak Sesuai untuk Selamanya (N2) berada di kecamatan Praya Barat Daya sebesar 7092,289 ha.

3. Kelas kesesuaian tertinggi untuk tanaman padi Gogo katagori Sangat Sesuai (S1) adalah 0, Cukup Sesuai (S2) berada di kecamatan Jonggat sebesar 5639,211 ha, Sesuai Marginal (S3) berada di kecamatan Pujut sebesar 18839,240 ha, Tidak Sesuaia Saat Ini (N1) berada di kecamatan Pujut sebesar 769,832 ha, Tidak Sesuai untuk Selamanya (N2) berada di kecamatan Praya Barat Daya sebesar 6229,360 ha.

\section{Saran}

Aspek lain yang perlu dikaji untuk penelitian lebih lanjut ialah aspek ekonomi, politik, dan kebijakan pemerintah setempat. Penyajian hasil dalam bentuk peta yang lebih detail, misalnya sampai tingkat admnistrasi desa, sehingga akan memudahkan pengguna serta evaluasi dengan mempertimbangkan kondisi irigasi setempat.

\section{DAFTAR REFERENSI}

Anonim $^{1}$. 2015. NTB dalam Angka 2015. BPS Provinsi Nusa Tenggara Barat. Lombok Barat.

Anonim ${ }^{2}$. 2009. Budidaya Tanaman Padi. Badan Ketahanan Pangan dan Penyuluh Pertanian Aceh Bekerja Sama dengan Balai Pengkajian Teknologi Pertanian Nusa Tenggara Barat. Mataram.

FAO (Food and Agriculture Organization). 1976. A Framework for Land. Evaluation.

Hardjowigeno, Sarwono dan Widiatmaka. 2007. Evaluasi Kesesuaian Lahan dan Perencanaan Tata Guna Lahan. Gadjah Mada University Press. Yogyakarta.

Nazam, Mohammad., Fitria, Zulhaedar., Ahmad, Suriadi., dan Sudjudi. 2014. Pewilayahan Komoditas Pertanian Berdasarkan Zona Agroekologi Skala 1:50.000 di Kabupaten Lombok Tengah dan Lombok Utara. Jurnal Penelitian Balai Pengkajian Teknologi Pertanian Nusa Tenggara Barat. Mataram.

Purwono dan Heni, Purnamawati. 2010. Budidaya 8 Jenis Tanaman Unggul. Penebar Swadaya. Jakarta.

Ritung, S., Wahyunto, Fahmuddin, A., dan Hapid, H. 2007. Panduan Evaluasi Kesesuaian Lahan Dengan Contoh Peta Arahan Penggunaan Lahan Kabupaten Aceh Barat. Balai Penelitian Tanah dan World Agroforestery Centre (ICRAF). Bogor. 